\title{
Labor market in Romania and Germany - comparative analysis in the context of macroeconomic stability and knowledge management
}

\author{
Alin Ioan CRETU ${ }^{1}$ \\ Laurentiu TESCAN ${ }^{2}$
}

\begin{abstract}
In Romania - like everywhere in the, world - labor demand is directly related to the macroeconomic and political stability in the country. By default strong investors are attracted to this stability. To this, it is obvious that the provision of reduced tax rates simultaneously with a series of technical conditions concerning transport and energy infrastructures. Of course, a well-trained workforce in optimal wage conditions. An essential contribution to the area of regional development and to the increase in the professional level of human resources, of course, is the use of knowledge management as a basic strategy and tool.
\end{abstract}

Key words: macroeconomic and political stability, low taxing, professional HR, knowledge management, honest political class, selfishness in government

JEL classification: M 00, M 12, M 52, M 54

DOI: $10.24818 / \mathrm{RMCI} .2019 .3 .323$

\section{Introduction}

Labor demand is directly related to the macroeconomic and political stability in the country. By default strong investors are attracted to this stability. To this, it is obvious that the provision of reduced tax rates simultaneously with a series of technical conditions concerning transport and energy infrastructures. Germany is an incontestable proof that no matter how ruined a nation would be, from a socio-economic point of view, through an honest political class and powerful leaders, it will give birth to a real economic empire. Germany's policy was from all-around, one based on the massive involvement of society and domestic and international politics in economic activities. Nowadays, German society is crossing a reference area with an economy that many call it "The Train of Europe," with a rate of of very low unemployment, at the same time as a GDP per capita at the highest level in Europe.

\footnotetext{
${ }^{1}$ CRETU Alin Ioan, Academy of Economic Studies, ETA Faculty, cretu.alinioan@yahoo.com

2 TESCAN Laurentiu, Ph.D., Academy of Economic Studies laurentiu_tescan@yahoo.com
} 
We chose Germany as a benchmark, because the Romanian society has long aspired to a model of development similar to that of Germany. I think that the main reason for the major differences between the two states is given by their political classes, the political elite of Germany joining forces in the key development projects of the country, regardless of the political color of the parties, while in Romania egoism is practiced in government, this means changing the legislative framework in the interest of the ruling party regardless of the party's political color, but unfortunately against the national economy and the citizens (MALHOTRA, 2005).

\section{Labour market in Romania}

\subsection{Description of the Romanian labour market}

The labour market is the area of economics where workforce demand, through employers, meets, confronts and negotiates with workforce supply owned by labourers. As such, the labour market client is the employer owning jobs, the supplier is the person seeking a job - employee, the transaction object is the workforce and the price is the whole salary, also known as individual salary fund. The workforce is offered by qualification levels and time units (MARTENSSON, 2000).

The labour market started to take shape in Romania subsequent to the 1989 events, based on a new theory which views labour as extremely special merchandise. In addition, the key feature was the transition from a traditional employment model, based on job stability and somewhat lacking opportunities, to the current one, modern and widely open to opportunities while having a higher risk level.

The Romanian labour market does not yet have all the law regulations capable of avoiding distortions, the economy seems to be taking 'two speeds', by accumulating disparities between the strongly developed western part, where the statistics show a labour force crisis, and the east where the sole tangible revenue comes from unemployment benefits and the minimum guaranteed income.

As much as in any other country, the level of employment of the workforce in Romania is strongly related to stimulation of the economy, macroeconomic stability and the social inclusion policies.

\subsection{Workforce supply}

One could say that the evolution of workforce supply has known two stages - the one before the country's accession to the European Union and the other after said accession. 


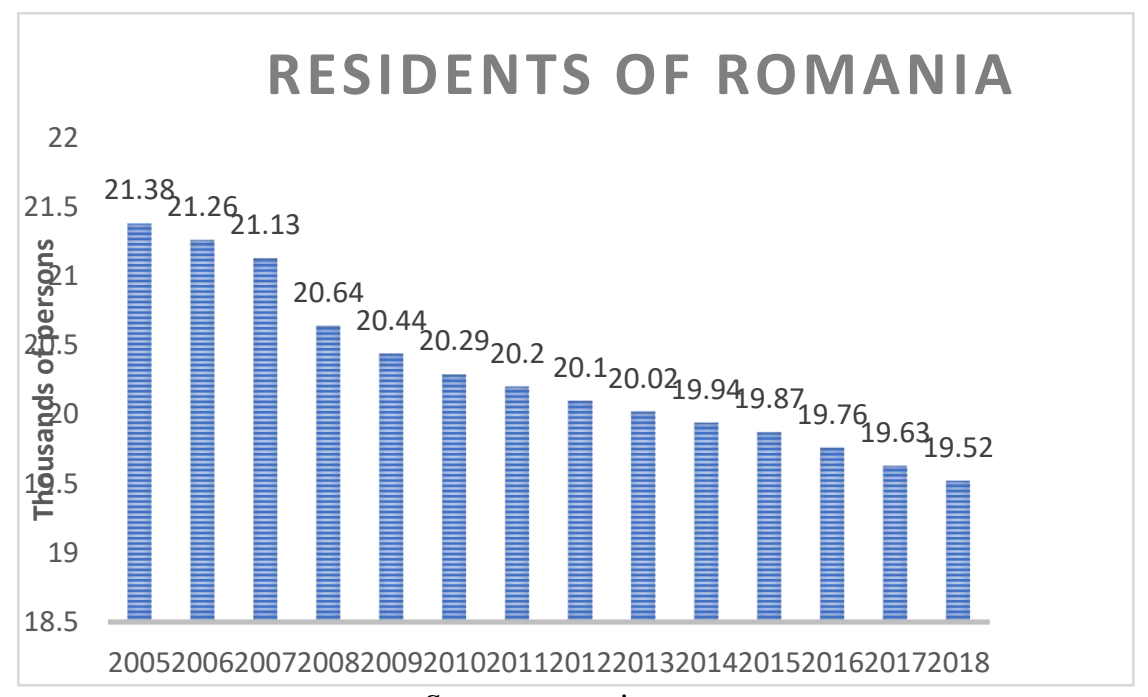

Source www,insse.ro

As shown in the graph above, before pre-accession, the resident population of Romania suffered a 250 thousand person loss - due to the European Union lifting visa requirements at the time, which correlated to an economic growth from 80 billion euro to 127.6 billion euro of the GDP in the 2005-2007 period. All resulted in an increase in job demand however not paired with a substantial increase in the average net salary, which went from 723 to 918 Eur. Therefore, the labour force was attracted to countries with better wage conditions at the time.

Subsequent to Romania's accession to the European Union, a significant increase could be noticed in terms of both average net salary and gross domestic product. As such, year 2008 showed the evolution of GDP to 146.5 billion euro from 127.6 billion euro in 2007; whereas over the same period, the average net salary went from 918 to 1200 . However, the workforce did not follow the trend, given that almost half a million persons in the workforce chose to leave the country, double as compared to the 2005-2007 period. The cause stood in the weak economic development in the post-communist time - crises, massive layoffs in the secondary sector as well as a weak absorption in other sectors as the primary and tertiary ones, all being encouraged by a lack of trust in politicians (LUBAN, BREAZU, 2005).

After the sudden crash of workforce supply, a quick decrease in workforce demand followed as a consequence of the international economic crisis, and manifested itself through layoffs in the private sector, and decreases and cuts in the budgetary sector. Consequently, the workforce migration from the country gained even more speed, and the workforce has sought for workforce demand outside the country. The graph shows that during the economic crisis, 2008-2011, approximately 450 thousand people had chosen to leave the country over a three year period. GDP decreased from 146.5 billion euro in 2008 to 131.9 billion euro in 2011. 


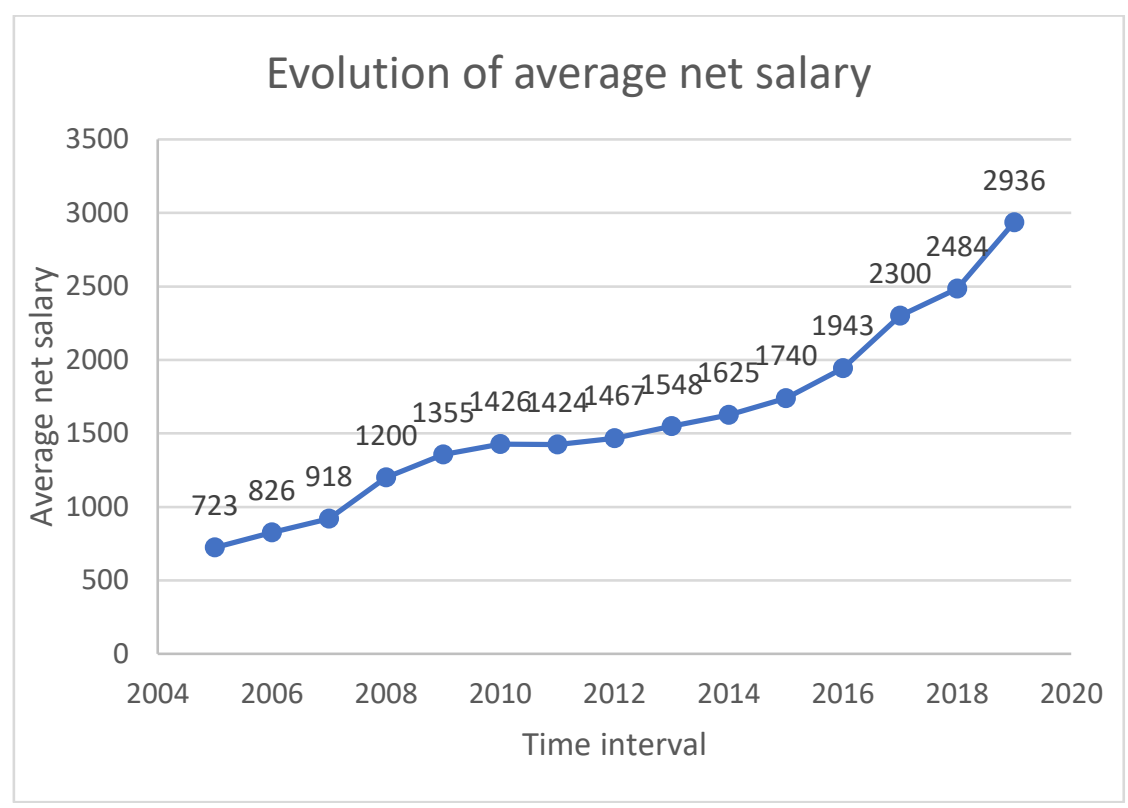

Source www,insse.ro

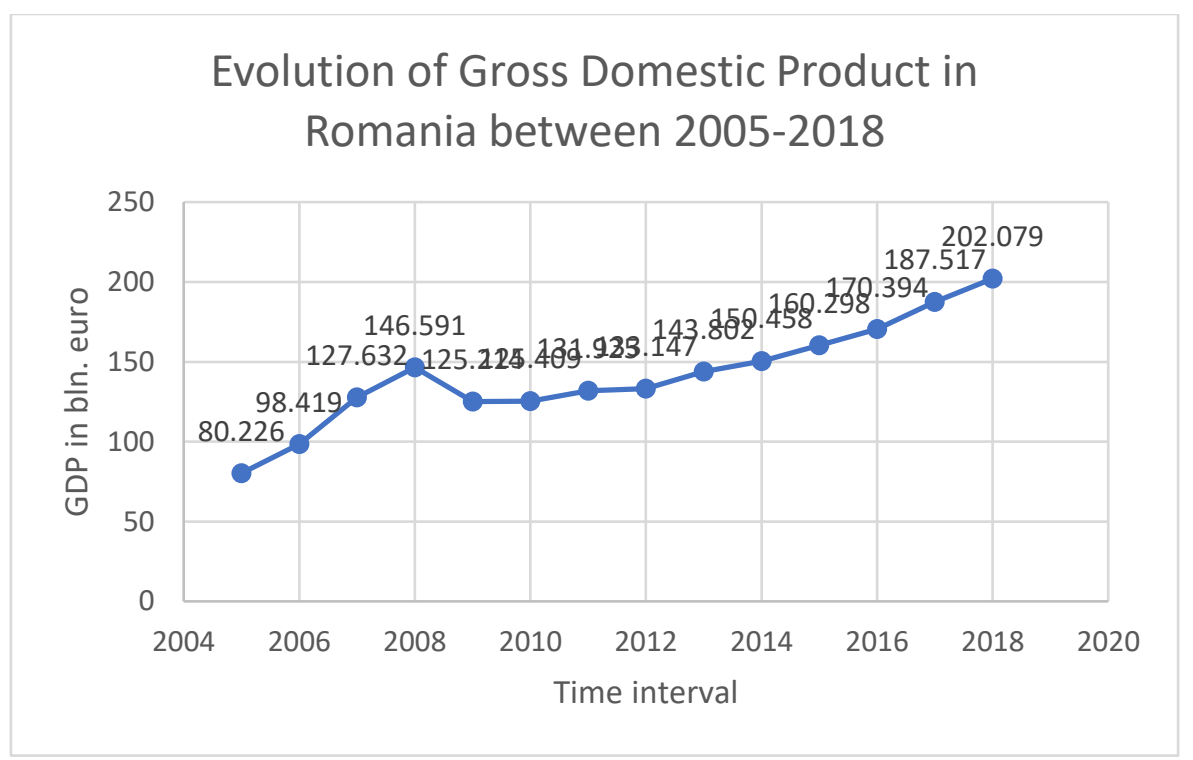

$326 \quad$ Volume 20, Issue 3, July 2019

Review of International Comparative Management 


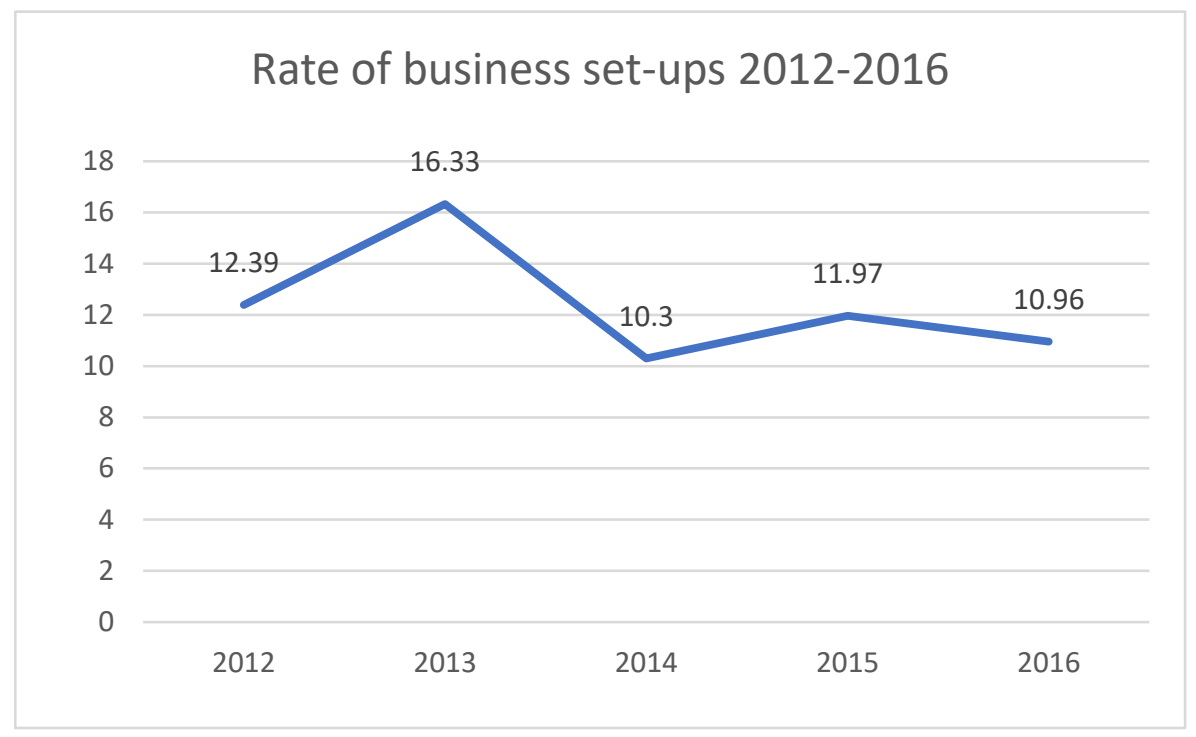

Source www,insse.ro

Average net salary evolved during the economic crisis, from 1200 Ron in 2008 to 1426 Ron in 2011 , based mainly on an increase in productivity aimed to re-launch economy and boost competition. After the re-launch, the average net salary underwent accelerated growth due to economic growth and workforce demand. However, the said evolution was unbalanced, e.g. according to Statistici Romania, in 2019, the average net salary equals 3099 Ron in Cluj county, but only 2094 Ron in Suceava county. Due to this inequality in income distribution at a national level, the national population decreased by approx. 680 thousand people during 2011-2018 (January).

\subsection{Workforce demand}

The workforce demand in a certain country is directly linked to macroeconomic and political stability - investors being attracted to open businesses in countries where taxation level is low and unchanged from one year to another or from one government to the next, and where the macroeconomic level is stable and predictable (MINCER, 1991).

Is Romania a stable country in terms of macroeconomics and politics? GDP evolution suggests Romania entered a trend of economic growth after the crisis, steadily increasing from 154.2 in 2011 to 196.4 in 2018. As for the political aspect, one could say that, in 2012, Romania transitioned from a liberal to socialist governance, so overall it could be stated that, until 2016, the country enjoyed political stability. All prerequisites for an increase in workforce demand were met, but let's see whether investors have chosen to open businesses in the territory. 
The graph illustrates a much bigger rate for the creation of businesses during the post-crisis period (2012-2013) than in the following years, the main reason being the re-launch of the national economy giving an opportunity to open new businesses. The shift from a liberal to a socialist government slowed the growth rate though, as the government at the time changed levies and taxes during 2013-2014. The political and economic stability is shown, however, in the alignment of the trend during 2014-2016. The 2015 shift from a socialist to a technocrat government somewhat decreased the rate, however insignificant, given that the transfer of power was made quickly and with no marked impact on macroeconomic stability.

During the post-crisis period (2012-2013), the businesses' dissolution rate was high, on account of the effects of the crisis on the national territory and of managers' inability to manage said crisis, with effects visible in companies' bankruptcy. After 2012-2013, the dissolution rate stood under 10\%, mainly due to the macro stability brought by the economic growth.

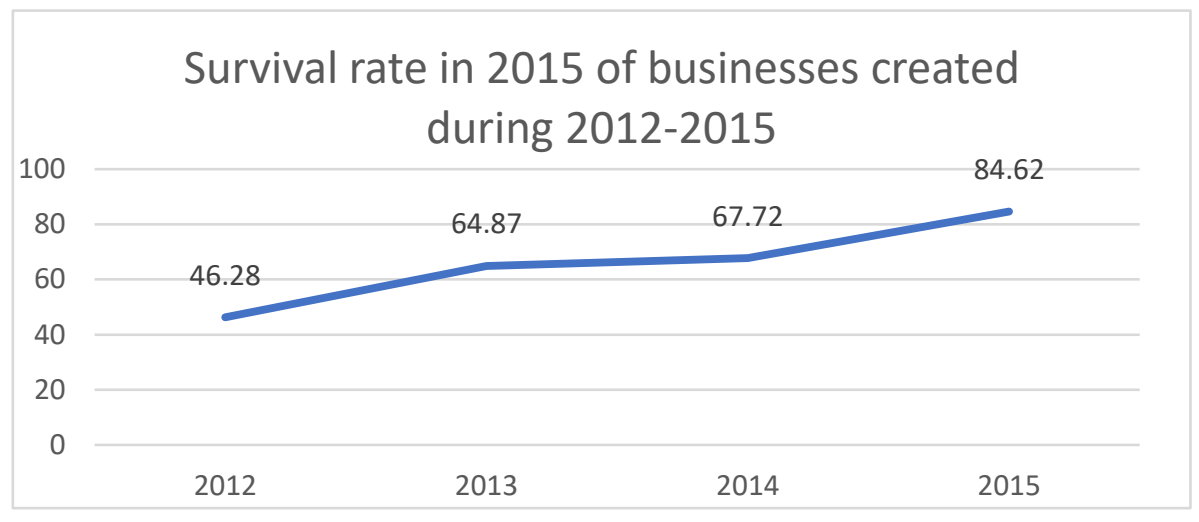

Source www,insse.ro

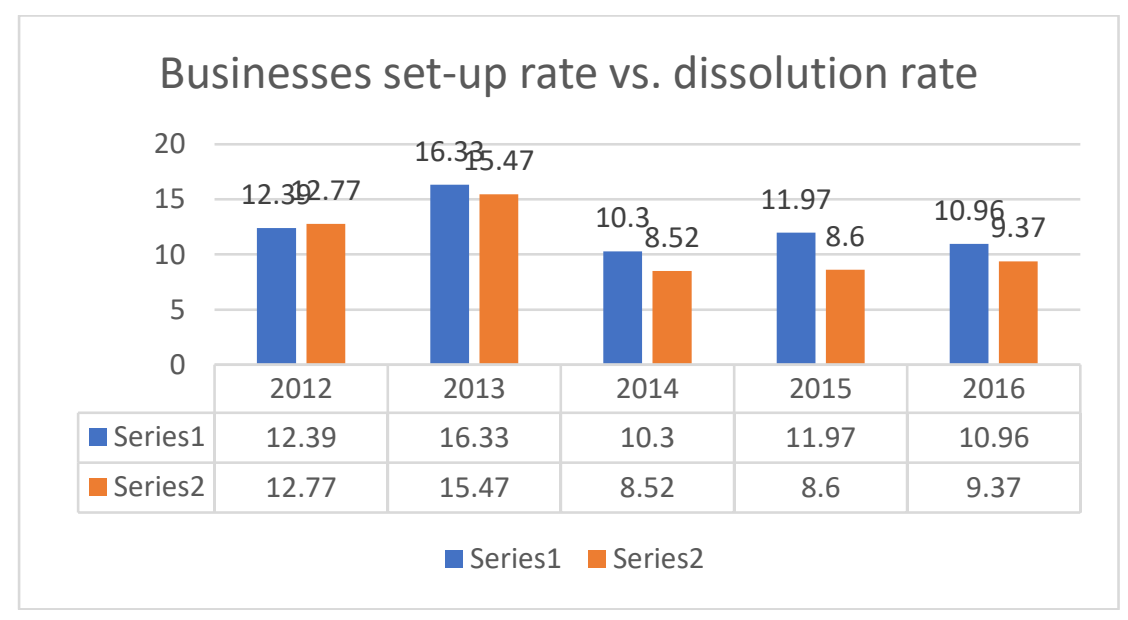

Source www,insse.ro 


\subsection{Unemployment in Romania}

Unemployment is such an important indicator of the economy of a country because it highlights people's wellbeing, and let me explain why that is! In theory, unemployment is a macroeconomic indicator. According to New Palgrave Dictionary of Economics, it is defined as 'the percentage of the labour force - the total number of people either working or seeking work - that is unemployed (but seeking)'. This indicator refers to people's wish to integrate into the economy of a country, meanwhile expressing the ability of the workforce demand to absorb this wish to integrate. Therefore it expresses people's wish to integrate into the economy, on the one side, and employers'ability to integrate people, on the other side (BODEA, 2000).

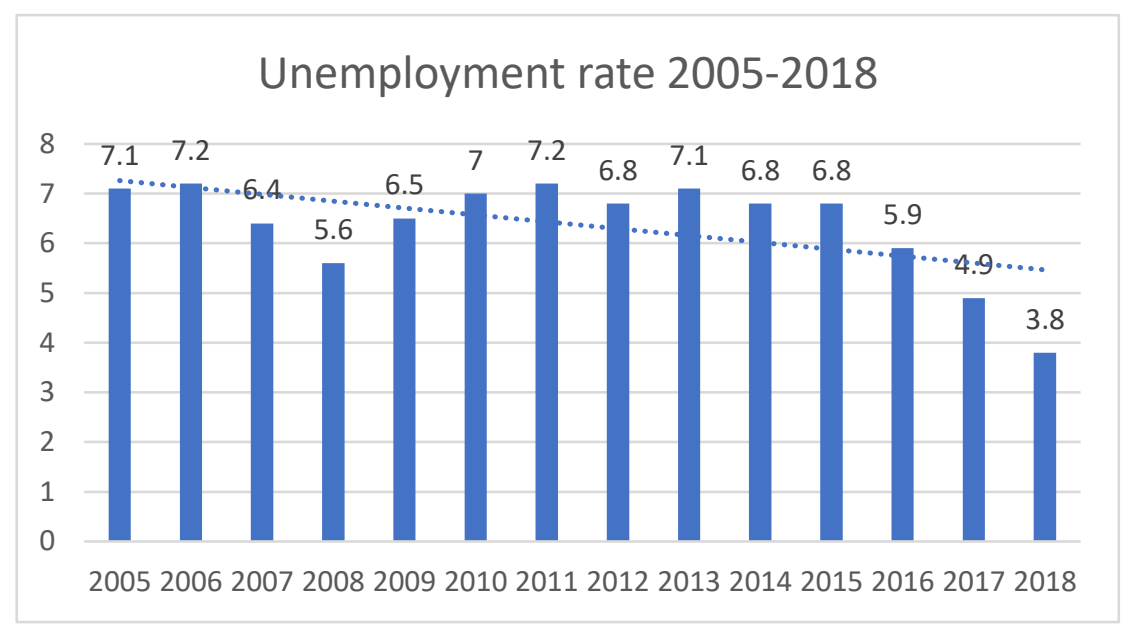

Source www,insse.ro

As seen in the graph, until 2016, unemployment rate failed to meet the less than 5\% threshold, and up until 2016 the trend was of a slight decrease as compared to 2016-2018, where annual differences mark one percentage point.

Prior to the economic crisis, unemployment rate reached its lowest level of 5.6\% - due to the pre-accession economic growth, but mainly to the 2007-2008 interval, the first year of membership to the EU for Romania. It was noticed both in the economic growth, with a marked increase in GDP, and in the average net salary increase. During the crisis, as all the other EU countries, Romania underwent restructuring measures - thus, in 2011, unemployment level had a significant increase of 1.6 per cent as compared to 2008. Post-crisis, the fluctuations in unemployment maintained between 7.2\%-6.8\% during 2012-2015, mainly driven by the market inability to recover after the crisis shock but also due to companies' caution with regard to any speedy expansion and to a subsequent lack of preparedness towards the economic cycle. The period from 2016 to 2018 is characterized by a steep decrease in unemployment, which was nevertheless 
caused not primarily by the absorption of unemployed by the economy but, by a large extent, to workforce migration abroad.

\subsection{Dynamics of employment by gender and age}

Throughout the period under analysis, the share of employment within the workforce remained constant, with some minor changes in answer to world macroeconomic events (LIEBOWITZ, 2005).

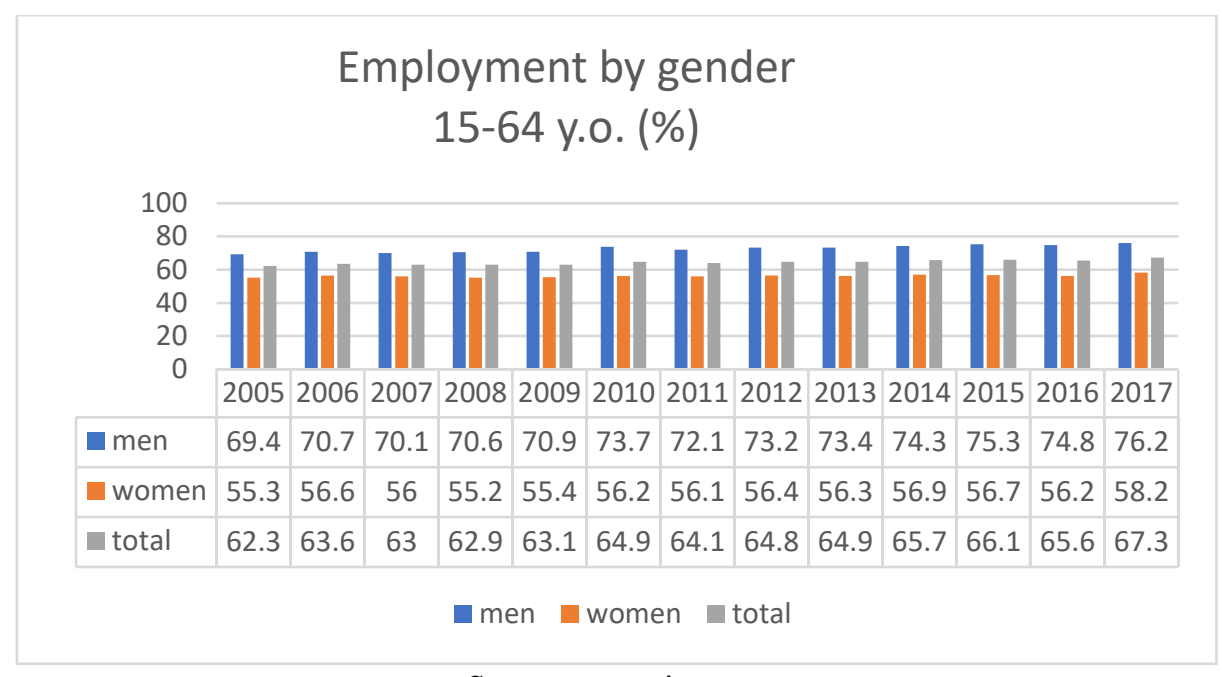

Source www,insse.ro

For Romania, the average of these years (2005-2017) reached $64.4 \%$ employed persons out of total active population. The only decrease, however insignificant was recorded in 2008 , of $0.1 \%$ as compared to 2007 , under the background of the economic crisis. Increases from one year to another differ for the most part due to Romania's accession to the EU - if, in the pre-accession period the increase was $1.3 \%$, post-accession and after the economy re-launch, increases reach $1.8 \%$.

Distributed by gender, men have a clear-cut larger share of employment than women, with all years' average over $70 \%$. A level of employment under $1 \%$ was only registered during the economic crisis, while the year-on-year in the other periods surpassed 1\%. As for women, employment rate is around $56 \%$. Year-on-year evolution does not follow that of men, their constant increase being replaced with a stagnation around the $56 \%$ value, with little increase/decrease fluctuations (ANDONE, 2003). For the last year though, a true leap of $2 \%$ could be noticed, most likely marking women's wish to get involved in the economic activity. The trend shows another change in women's employment rate for the years to come (GUSTAVSSON, 2002).

$330 \quad$ Volume 20, Issue 3, July $2019 \quad$ Review of International Comparative Management 


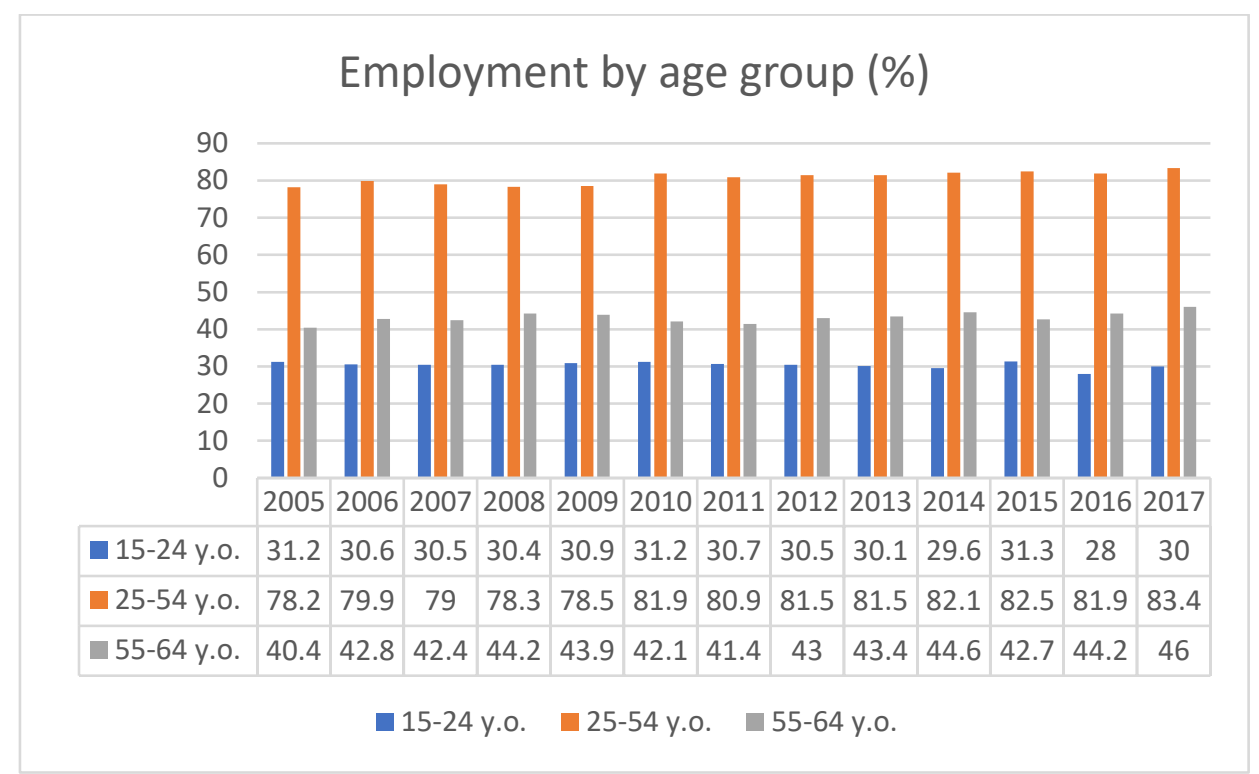

Source www,insse.ro

By age groups, the 25-54 year-olds leads the share of employment by far, most of them choosing to enter the workforce after finishing studies. Years' average is $80 \%$, with little variation given by the macroeconomic background on the market - but, as a trend, a gradual increase of employment per cent within the 25-54 year-olds group could be noticed.

In regard to the 15-24 year-olds group, the trend is linear over the years, with some small fluctuations indicating employers' involvement in recruiting and training future employers as early as during their study years (MUNTEAN, DĂNÄIAŢĂ, MARGEA, 2001).

For the 55-64 year-olds category, evolution fluctuates, for the most part under the influence of legislation and of retirement terms - if favourable terms are in place, people choose to retire, and if not, they choose to remain in the workforce up to the legal upper limit.

\subsection{Romanian state policies on labour market}

Each and every member state or accession state must develop a National Strategy on Employment and a National Action Plan on Employment, with both documents monitored at EU Community level. The foundation pillars of the strategy in each country find convergence with the European strategy objectives on employment, objectives being adapted to particular conditions (NICOLESCU, 2001).

The National Action Plan on Employment (NAPE) is a priority objective of the alignment to the European strategy on employment, under the background of Romania's preparation for accession to the European Union. NAPE was 
drafted on the basis of guidelines of the European strategy for employment as adopted each year by the Council of the European Union.

In order to reach the objective, the member states (as well as those in accession and pre-accession stages) must react by adapting to the guidelines governed by the four pillars, through a general coherent strategy which has to encompass the following horizontal objectives:

Horizontal objective A - Increase of employment rate. Proposed measures aim to stimulate job creation, under the backdrop of a speedy continuation of privatization and restructuring. Moving emphasis from passive to active measures within the policies for unemployed protection is envisaged here.

Horizontal objective B - National strategies for 'lifelong learning'. Law and institutional reforms corroborate with larger funds allotted to education and training, showing an interest to the development of extensive, coherent national strategies in the field of initial and continuous training.

Horizontal objective C - Development of social partnership. Given the fact that at this time the Romanian economy has to adapt itself through all sectors in order to become and stay competitive, the social partnership becomes an effective way to ensure modernization and diversification of activities.

Horizontal objective D - Regional dimension. The development regions are the framework within which regional development policy and economic and social cohesion programmes are conceived, implemented and evaluated. The employment policy and the professional training policy are the ones to give directions to the regional initiatives.

Horizontal objective $\mathbf{E}$ - Development of a system of indicators for the labour market. In order to develop coherent policies and adequately monitor and assess progress made in the implementation of NAPE, suitable statistics information is required.

\section{Labour market in Germany}

\subsection{Description of the labour market in Germany}

To many, Germany is proof that no matter how economically and socially ruined a country may be, an honest political class with strong leaders would make an empire rise again from its ashes. Since its funding until today, Germany's politics have been based on society, and on the involvement of society in the economic activity to the largest possible extent - and so it is that today's society in Germany lives its richest days in the last century, with an economy labelled by many as 'Europe's engine', an employment rate at the lowest level since reunification and the biggest GDP per capita in Europe; it is the country where many wish to raise their children. For all that, not everything is perfect, as Germany is confronted with an excess of migration from the conflict zones in Syria and the Middle East, and the politicians have to face integration of a significant number of people who came to start all over in a country that's 
civilized and, above all, safe (MUMFORD, 2000). The German labour market stands on a specific mix of flexibility and security, by adjusting salary levels based on supply and demand while maintaining labour security through laws initiated by the federal government.

\subsection{Workforce supply}

Workforce supply in the German market is largely balanced, with a slight increase in the last years on account of the large number of migrants from Syria and the Middle East.

Before the crisis, the workforce supply was growing in the context of the pre-crisis economic growth correlated to an increase in the GDP per capita - all making it a desirable country to migrate to at the time, from both the inside and the outside (as, e.g., Romania) of the European Union. After the world crisis developed and a sharp decrease of GDP ensued, affecting all the community block economies, a diminishing workforce supply could be observed in response.

The crisis once overcome and Germany re-launching its economy, the workforce supply started to take an ascending trend, which in turn led to an increase of residents in Germany. The new challenge Germany has to face is integration of the people who reached its territory from 2015-2018, around one million persons arriving from conflict zones. This is nevertheless beneficial for the German economy, as it fights the population aging phenomenon - and thus the federal government is able to postpone the new reforms in the social sector, namely the extension of the retirement age.

\subsection{Workforce demand}

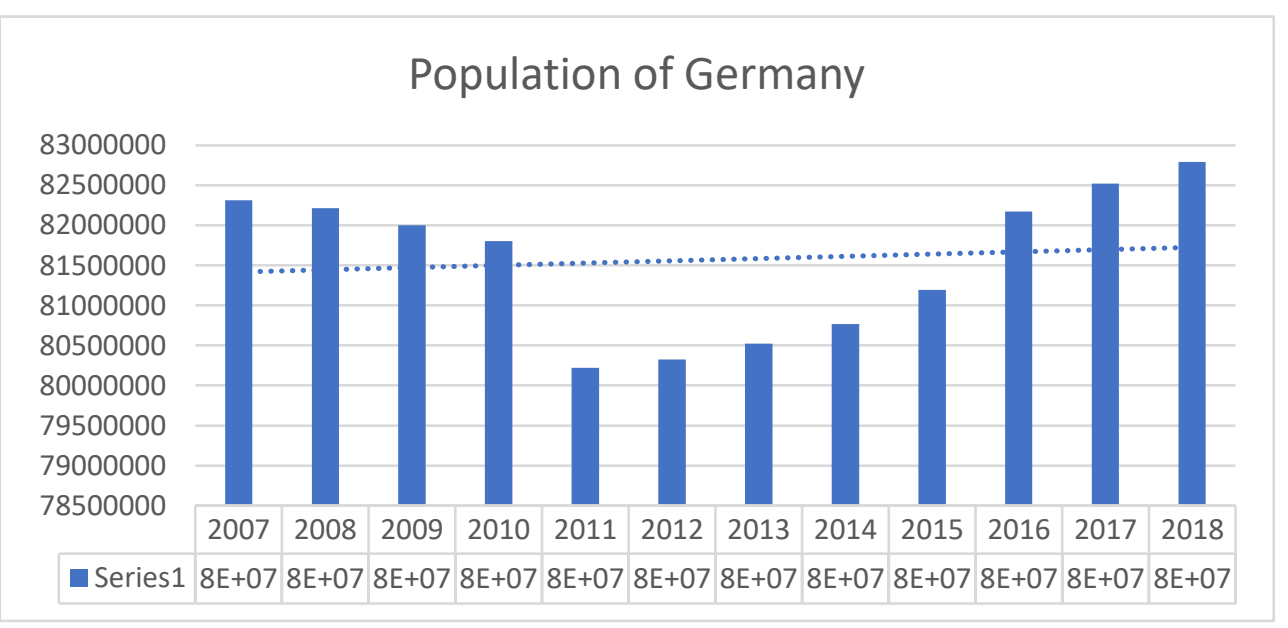

Review of International Comparative Management

Volume 20, Issue 3, July 2019 
In terms of workforce demand, Germany is a strongly developed economy; therefore the international economic events affected Germany to a lesser extent as compared to the other EU countries. As an example, Germany succeeded to overcome the crisis in 2010 , whereas the other states did so only in 2011, and with great cost.

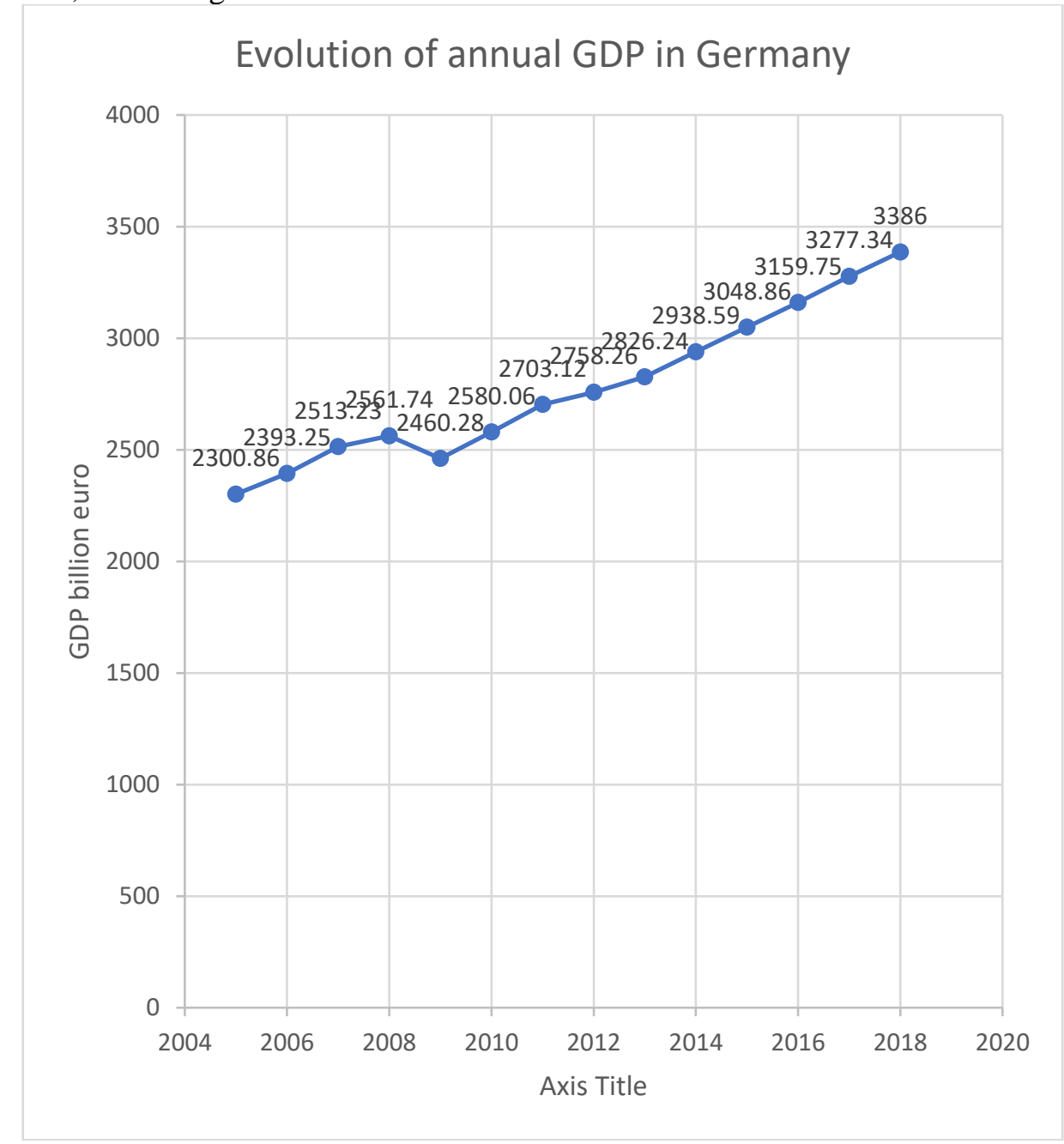

Source: https://ec.europa.eu/eurostat

On a 12 years period, Germany's economy succeeded to grow from 2393 billion euro in 2006 to 3386 billion euro in 2018, taking in account that 2009 was a year of economic crisis, leading to a decrease in the workforce demand.

On a less than ten years period, Germany's economy has grown with approximately 500 billion USD - from 2513 billion USD in 2007 to 3048 billion USD in 2015. We should take into account that Germany's economy is based upon the automotive industry, as the WV group is the leading automobile 
producer worldwide, with some 11 million cars sold in 2017, while the main competitor, Mercedes-Daimler \& BMW, has its main production facilities also on German territory. The journalist Moise Guran stated in an interview comparing the Romanian industry with the German one that 'We are far from being Germany, as Germany makes Mercedes and Romania makes Dacia'. Germany's power comes from these employers who ultimately sustain the country's workforce demand - if these employers yield Germany yields as well. Therefore, workforce demand is directly linked to the economic development of a certain country: a well-developed economy brings about raised values in workforce demand (DAVENPORT, 1998).

\subsection{Unemployment and population income}

Whenever in an economy the population (workforce supply) is constant and the economic growth (workforce demand) increases at speed, we will encounter unemployment rate decrease on the labour market (JARVINEN, POIKELA, 2005). As seen in the graph above, the economic growth prior to the crisis had a significant impact on the unemployment rate: over the 2005-2008 period, it diminished with more than 3.5 per cent. Anyway, the impact of crisis on economy was less noticeable for a country such as Germany, as compared to other European states such as Italy or Spain, so that the unemployment rate increased by only 0.3 per cent from 2008 to 2009 . The said phenomenon largely owes to the government action choosing to alter work hours instead of pursuing massive layoffs (DRUCKER, 1994). It could be said that, after the economic crisis, the change in unemployment rate closely linked to Germany's economic growth - reaching, in 2018, the lowest level of unemployment after reunification.

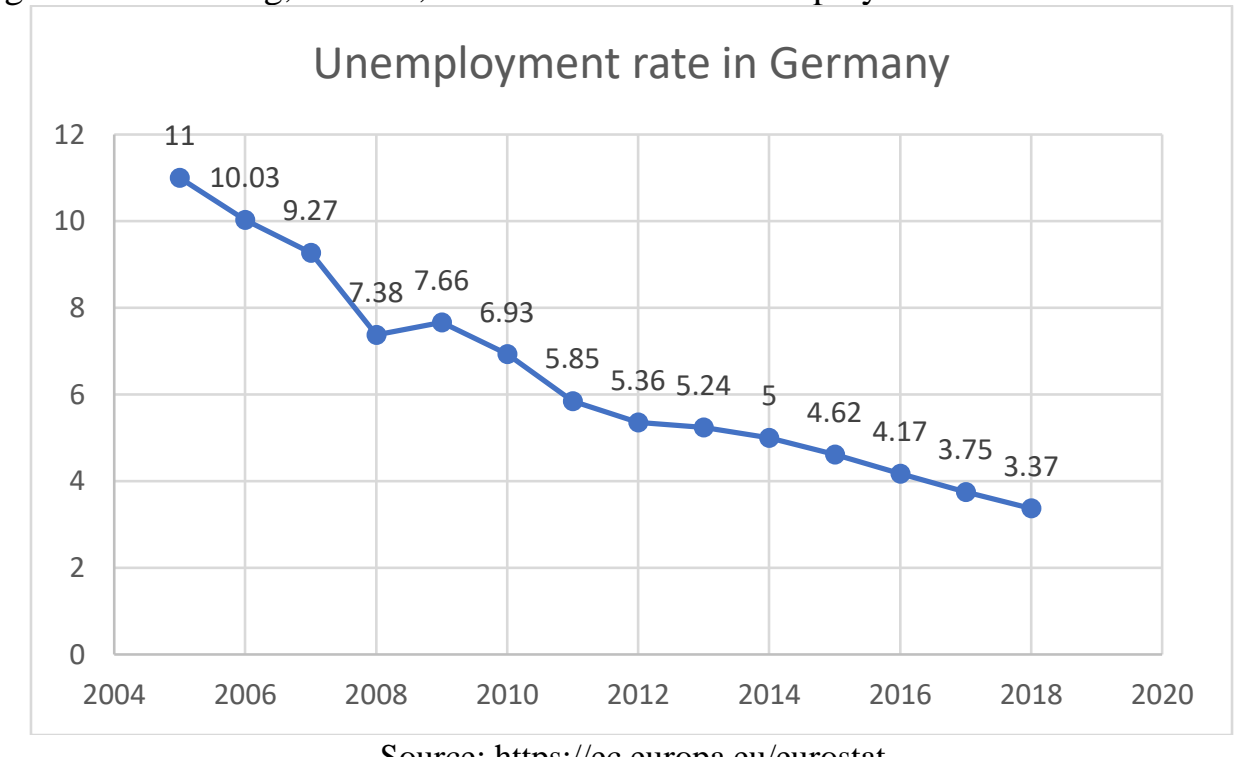

Source: https://ec.europa.eu/eurostat 
Directly proportional to the evolution of workforce supply and demand is the population income, so when on the labour market the number of people is constant and the workforce demand is high, we will encounter valued labour employers willing to pay more for employee retention (NONAKA, 1991).

The sole income decrease occurred during the economic crisis, otherwise the German population income constantly grew in line with the economic growth of the country - in other words, the economic growth truly felt in their pockets, as the GDP per capita raised from 28.300 euro in 2005 to 40.900 euro in 2018 - an evolution of 12.600 euro over a period of only 13 years.

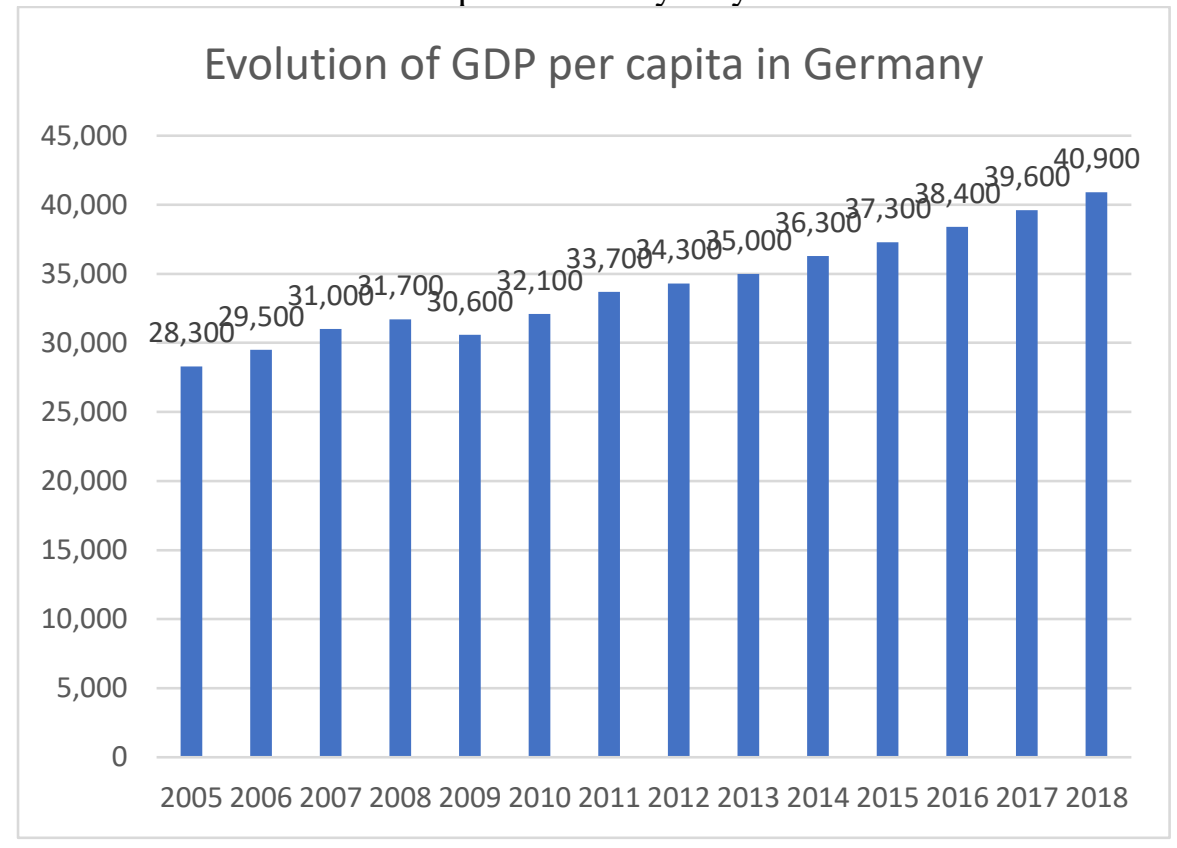

Source: https://ec.europa.eu/eurostat

\section{Romania-Germany comparison}

By means of a comparison between Romania and Germany, I wish to highlight the different visions the two countries' policies apply in the matter of labour market. I have chosen Germany for comparison as it is one of the most developed countries on the continent, and the Romanian society has been yearning for a long time (too long already, in my opinion) to such a development model as the German one. In my view, the main reason is the political class of the two countries - the German political elite, no matter the political orientation, joining forces in the strategic development projects of their country, while in Romania selfishness is practiced by governance i.e. the law framework is changed whenever profitable, notwithstanding the affected citizens' interests which should prevail (SANCHEZ, CHAMINADE, OLEA, 2000). 


\subsection{Workforce supply}

Workforce supply over the analysed period had a linear evolution both in Germany and Romania, with little fluctuation on account of the economic crisis but stable overall (IANCU, 2003). There is a distinction though - unidentifiable in the period but noticeable on long term; namely, an increase of persons in Germany and decrease of persons in Romania. In the case of Romania, this is attributable to the lack of vision in maintaining the workforce, and to the unsatisfactorily correlated level of salary to the effort - so that people choose to leave for countries as Germany, where work done is paid accordingly.

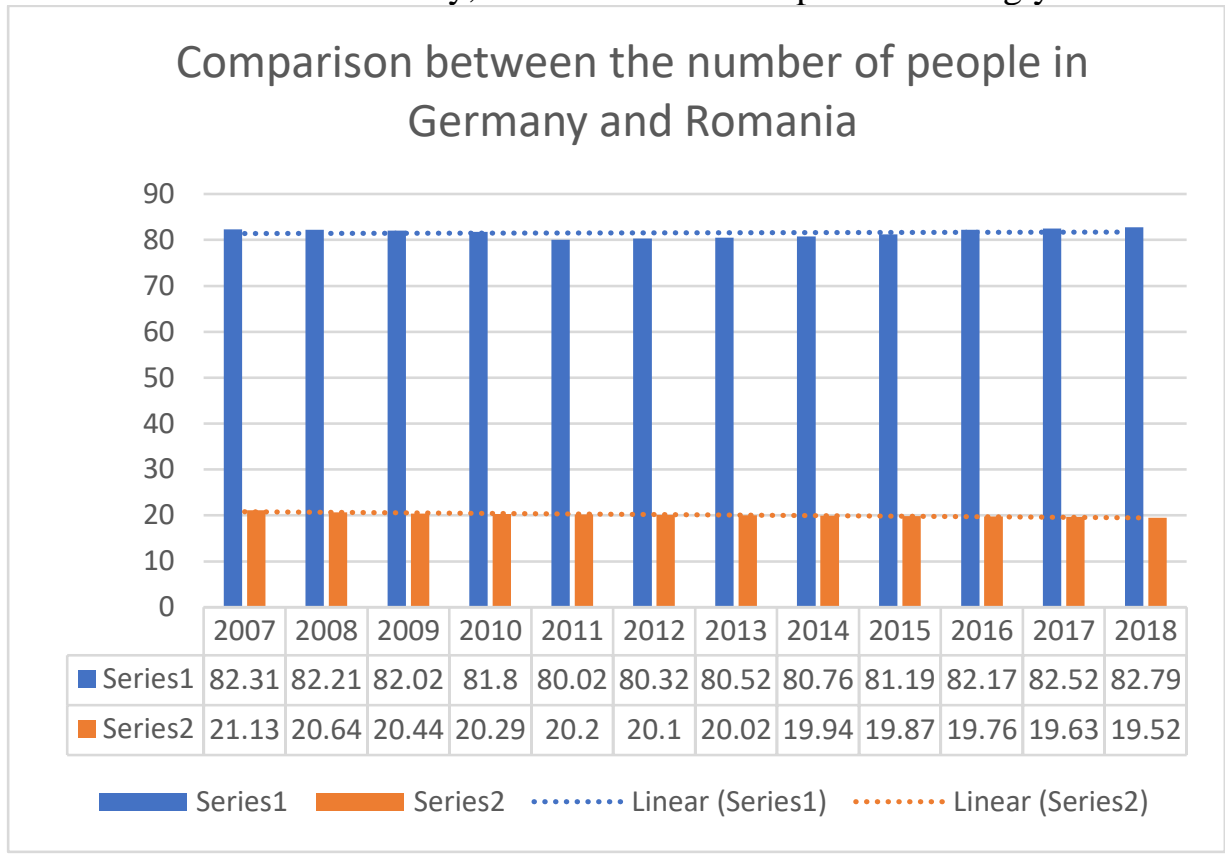

Source: Personal statistical data processing

\subsection{Workforce demand}

This is a chapter Germany performs very well at, as we may see from its GDP growth. Romania enjoys a positive trend as well, yet the GDP growth rate is markedly inferior to the one in Germany. This may be easily noticed from the graph, where Germany reaches during a trimester the same growth in billion euros of GDP as Romania gets in one year (Rosca et all, 2002). Let's keep in mind that Germania makes Mercedes and Romania makes Dacia. On long term, a significant increase in Germany's GDP from one year to another can be seen. Evolution in Romania remains modest, but still exists, so that we may talk about an increase in workforce demand on both markets. 


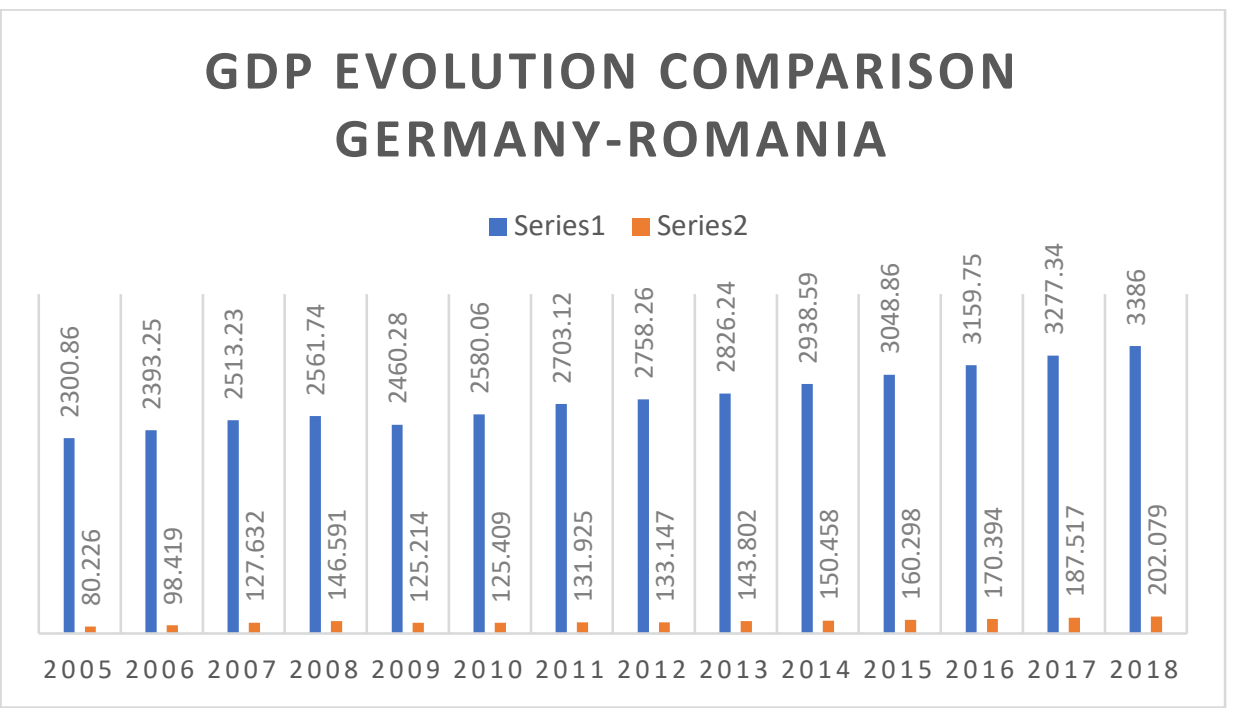

Source: Personal statistical data processing

\subsection{Unemployment and GDP per capital}

A good labour market policy reflects in the evolution of unemployment rate (HARRISON, 2003). Social policies and labour market regulations brought Germany a down curve in the evolution of unemployment, with an accelerated rhythm of decrease, whilst Romania also took a downward curve, but in a slower rhythm and some little year-on-year fluctuations.

\section{Unemployment rate comparison Germany-}

\section{Romania}

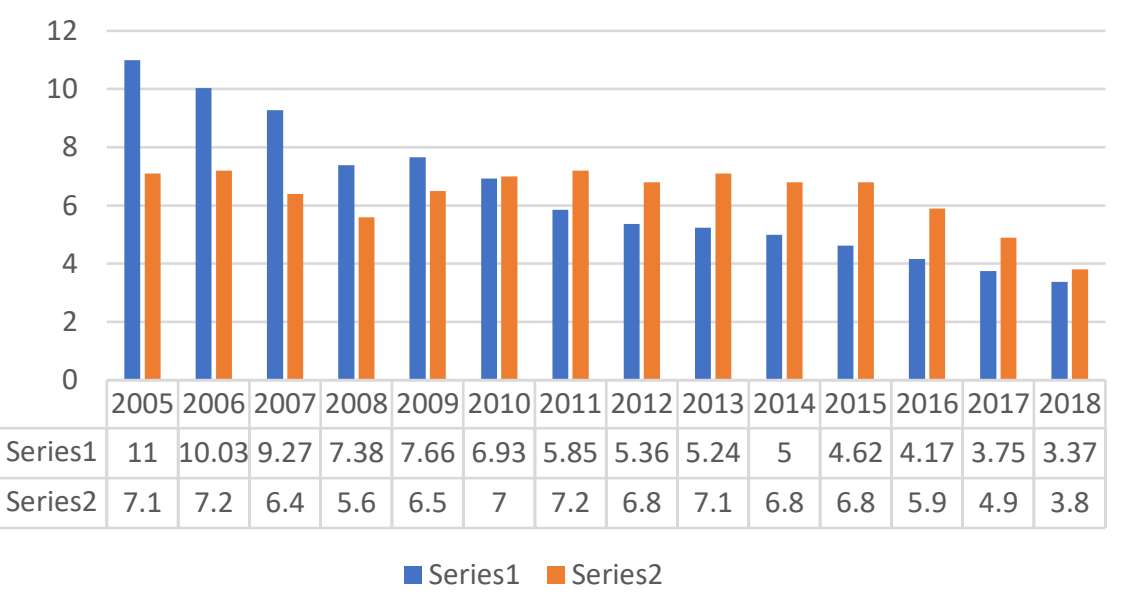

Source: Personal statistical data processing 
In regard to the GDP per capita, Germany leads by far, as in 2018 succeeded to pass the 40.000 euro per capita threshold, while Romania passed the 10.000 euro threshold. Big differences in income reside in the big difference in economic growth and since economic growth is reflected in contributors' wallet, it turns much more gain in Germany than in Romania.

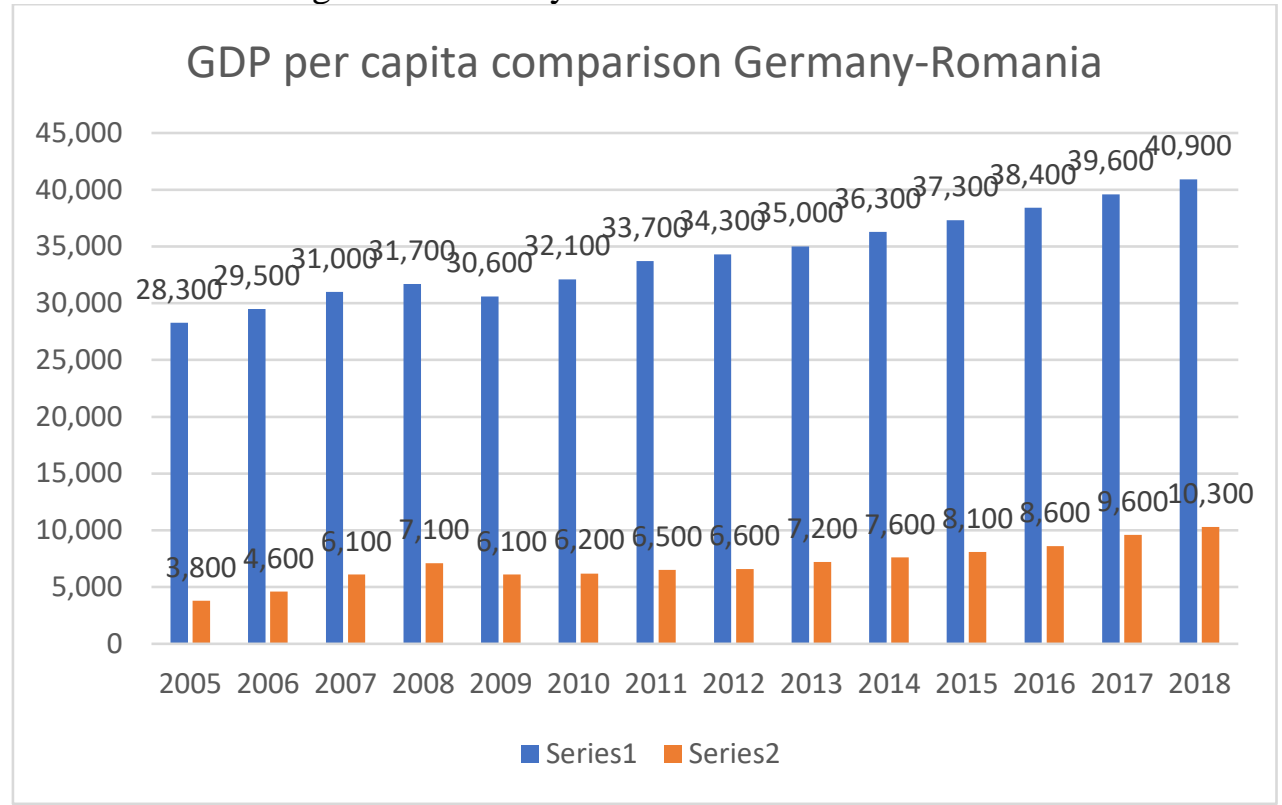

Source: Personal statistical data processing

\section{References}

1. ALINA S., CHENIC, (2012) O analiză de actualitate a evoluţiilor şi structurilor pe piaţa muncii în Uniunea Europeană în corelaţie cu cerinţele flexicurităţii pieţei muncii. Articol [Online]. Vol XIX, pp. 76-95. Disponibil la adresa. http://www.store.ectap.ro/articole/700_ro.pdf

2. ALINA S., CHENIC, (2013) Aspecte ale flexicurităţii pieței muncii în modelele mediteranean şi anglo-saxon. Articol [Online]. Vol XX, pp. 65-80. Disponibil la adresa. http://www.store.ectap.ro/articole/700_ro.pdf

3. AFRODITA, C., Ziarul Adevarul [Online].Disponibil la adresa https://adevarul.ro/economie/stiri-economice/ce-modificari-aduce-2019piata-muncii-domeniile-vor-concedieri-1_5c0fcfaadf52022f7559c52f/ index.html

4. ANCA, O.,Wall-street [Online].Disponibil la adresa https://www.wallstreet. ro/articol/Careers/230851/piata-muncii-in-statele-uniunii-europene-catepersoane-lucreaza-in-romania.html

5. https://ec.europa.eu/social/main.jsp?langId=ro\&catId=1172\#navItem-2 
6. ARGYRIS, C. - On Organizational Learning, Oxford, Blackwell Business, 1993

7. ARGYRIS, C.; SCHON, D. A. Theory in practice increasing professional effectiveness, San Francisco, Jossey Bass, 1978

8. ANDONE, I. „Valoarea cunoaşterii în societatea bazată pe competiţie”, în Revista Informatica Economică nr. 1 (25), 2003, pp. 7-13

9. BECKER, G. S,,Investment in human capital: A theoretical analysis”, în Journal of Political Economy, 70(5), 1962, pp. 9-49

10. BENDER, S. FISH, A. ,The transfer of knowledge and the expertise: the continuing need for global assignments", în The Journal of Knowledge Management, 4, 2000, pp. 125-137

11. BODEA, C. „Inteligenţa artificială şi managementul cunoştinţelor economice", în Revista Informatica Economică nr. 1 (13), 2000, pp. 5-11

12. BOUDARD, E. Literacy proficiency, earnings, and recurrent training: A new country comparative study. Studies in Comparative and International Education 57, Institute of International Education, Stockholm University, 2001

13. CHASE, R. L. „The knowledge - based organization. An international survey" în The Journal of Knowledge Management, 1, 1997, pp. 38-49

14. COMISIA EUROPEANĂ A memorandum on lifelong learning. http://europa.eu.int/comm/education/policies/III/life/memoen.pdf, 2000

15. COSMIN, C., Disponibil la adresa http://www.referatele.com/- referate/ economie/online13/Piata muncii-in-Romania---Caracterizarea-pietei-munciiin-Romania-evolueaza-in-directia-apropierii-d.php

16. DAVENPORT, T. H. DE LONG, D.W. BEERS, M.C. „Successful knowledge management projects" în Sloan Management Review, 39, 1998, pp. 43-57

17. DAVENPORT, T. H. PRUSAK, L. Working knowledge: How organizations manage what they know. Boston, Harvard Business School Press, 1998

18. DRAGOMIRESCU, H., Organizaţii bazate pe cunoaştere. Studiu tematic al Academiei Române. elaborat în cadrul proiectului prioritar "Societatea informaţională - societatea cunoaşterii" Bucureşti, 10 noiembrie 2001 http://www.academiaromana.ro/pro_pri/pag_com01socinf_tem.htm, 2001

19. DRUCKER, P. „The coming of the new organization”, în Harvard Business Review, 66(1), 1988, pp. 45-53

20. DRUCKER, P. „The new society of organizations” în Harvard Business Review, 70(5), 1992, pp. 95-104

21. DRUCKER, P. ,The theory of business” în Harvard Business Review, 72(5), 1994, pp. 95-104

22. EASTER-SMITH, M. „Introduction: Watersheds of organizational LYLES, M. A. learning and knowledge management", în Handbook of organizational

$340 \quad$ Volume 20, Issue 3, July $2019 \quad$ Review of International Comparative Management 
learning and knowledge management, Oxford, (M. Easter-Smith, M.A. Lyles eds.), Blackwell Publishing Ltd., 2003, pp. 1-17

23. EDVINSON, L. MALONE, M. S. Intellectual capital: Realizing your company's true value by finding its hidden brainpower, New York, Harper Business, 1997

24. FLORINELA, I., Ziarul Adevarul [Online].Disponibil la adresa https://adevarul.ro/news/societate/eurostat-romania-topul-tarilor-cele-maiputine-femei-integrate-piata-muncii1_5bcdf16cdf52022f75c20ae7/index.html

25. GUSTAVSSON, B. „What do we mean by lifelong learning and knowledge?" în International Journal of Lifelong Education, 21, 2002, pp. 13-23

26. GUTHRIE, J. PETTY, R. JOHANSON, U. „Sunrise in the hnowledge economy: managing, measuring and reporting intellectual capital" în Accounting Auditing \& Accountability Journal, 14, 2001, pp 365-382

27. HANDZIC, M. CHAIMUNGKALANONT, M. „Enhancing organizational creativity through socialization" în The Electronic Journal of Knowledge Management, Vol 2 Issue 1, 2004, pp. 57-64, http://www.ejkm.com

28. HARRISON, S. J. Managing know-who based companies. A multinetworked approach to knowledge and innovation management. Cheltenham, Edward Elgar, 2000

29. HASAN, A. „Lifelong learning” în The international encyclopaedia of adult education and training, Oxford, A. Tuijnman Pergamon, 1996

30. IANCU, S. Cadrul legislativ al protecţiei drepturilor de proprietate intelectuală şi riscul de a nu stimula activitatea inventatorilor, 2003, http://www.icmpp.ro/institute/cap_iancu.doc

31. JARVINEN, A. POIKELA, E. „Modeling reflective and contextual learning at work" în Journal of workplace learning, 13, 2001, pp 282-289

32. KIM, D. H. „The linking between individual and organizational learning” în The strategic management of intellectual capital, Oxford, D.A. Klein ed. Butterworth - Heinemann, 1998, pp. 42-63

33. LEADER, G. „Lifelong learning: Policy and practice in further education” în Education + Training, 45, 2003, pp. 361-370

34. LIEBOWITZ, J. Building organizational intelligence: A knowledge management Primer, London, CRC Press, 2000

35. LUBAN, F. BREAZU, G. „Managementul cunoştinţelor” în Economia seria Management, 1-2, 2000, pp. 53-57

36. MALHOTRA, Y. Knowledge management in inquiring organizations, „Proceedings of 3rd Americas Conference on Information Systems Philosophy of Information Systems Mini-track", Indianapolis, IN, August 15-17, 1997, pp. 293-295 www.kmnetwork.com/km.htm 
37. MALHOTRA, Y. Why knowledge management systems fail. Enablers and constraints of knowledge management in human enterprises, in Koenig, M.E.D. and Srikantaiah, T.K. (Eds), Knowledge Management Lessons Learned: What Works and What

38. MALHOTRA, Y. „Integrating knowledge management technologies in organizational business processes: getting real time enterprises to deliver real business performance" în Journal of Knowledge Management, Vol. 9, No. 1, 2005, pp. 7-28 http://www.kmnetwork.com/RealTime.pdf

39. MARTENSSON, M. „A critical review of knowledge management as a management tool" în Journal of Knowledge Management, 4, 2000, pp 204-216

40. MINCER, J. „Human capital and the labour market: A review of current research", în Educational Research, 18(4), 1989, pp. 27-34

41. Ministerul muncii, familiei şi egalităţii de şanse direcţia programe şi strategii forţă de muncă. Articol [Online].Disponibil la adresa http://www.mmuncii.ro/pub/imagemanager/images/file/RapoarteStudii/261007rapsept.pdf

42. MUMFORD, M. D. „Managing creative people: Strategies and tactics for innovation." în Human Resource Management Review, 10(3), 2000, pp. 313-351

43. MUNTEAN, M. DĂNĂIAŢĂ, D. MARGEA C. „Managementul cunoştinţelor în societatea bazată pe cunoaştere", în Revista Informatica Economică nr. 2 (18), 2001, pp. 13 - 12

44. NONAKA, I. „The knowledge creating company”, în Harvard Business Review, 69(6), 1991, pp. 96-104

45. NONAKA, I. TAKEUCHI, H. The Knowledge-Creating Company: How Japaness companies create the dynamics of innovation, New York, Oxford University Press, 199539.

46. NICOLESCU, O. „Economia şi firma bazate pe cunoştinţe” în Investiţiile şi relansarea economică (Vasilescu I. şi Luban F. coordonatori). Ediţia a IV-a., Bucureşti, Editura ASE, 2001, pag. 38-53

47. OECD Towards the learning society of the $21 \mathrm{st}$ Century. 1996 http://www.oecd.org/dataoecd/33/59/19507638pdf

48. POLANYI, M. The tacit dimension, Second Edition, New York, Anchor Books, 1967

49. ROŞCA, I. APASTOL, C. G. ZAMFIR G. E-learning - paradigmă a instruirii asistate" în Revista Informatica Economică nr. 2 (22), 2002, pp. $5-17$

50. SANCHEZ, M. P. CHAMINADE, C. OLEA, M. „Management of intangible: an attempt to built a theory" în Journal of Intellectual Capital, 1(4), 2000, pp. 312-328 